UDC 378:147:331.45-051

DOI: https://doi.org/10.31470/2415-3729-2020-12-24-44

\title{
Modern Approaches to the Formation of a Professional Safety Culture in Future Labor Protection Specialists
}

\section{Mark Vaintraub}

Doctor of Sciences in Pedagogy (DSc), Professor, Professor of the Department of Theory and Methods of Vocational Training

Pereiaslav-Khmelnytskyi Hryhorii Skovoroda State Pedagogical University, $\triangle$ 30, Sukhomlynskyi Str., Pereiaslav, Kyiv Region, Ukraine, 08401

E-mail: vainmark2014@gmaile.com

ORCID: http://orcid.org/0000-0002-2701-7094

Date of receipt of the article: September 28, 2020 Article accepted for publication: November 22, 2020

\section{Сучасні підходи до формування культури безпеки професійної діяльності у майбутніх фахівців 3 охорони праці}

\section{Марк Абрамович Вайнтрауб}

доктор педагогічних наук, професор, професор кафедри теорії та методики професійної підготовки, ДВНЗ «Переяслав-Хмельницький державний педагогічний університет імені Григорія Сковороди», $\checkmark$ вул. Сковороди, 30, м. Переяслав, Київська обл., Україна, 08401 


\section{Abstract}

The article is devoted to the problem of formation peculiarities of safety culture of future health and safety professionals under modern conditions.

The security situation, which is under the influence of many complex dynamic processes, has been exacerbated by the anthropogenic pressure on the environment due to the pandemic, which is accompanied by the emergence of new risks and threats to humans. Therefore, the issue of people's life and health safety is considered a priority in the context of ensuring sustainable development of the state and society as a whole.

Ukraine has created a legal framework based on the Constitution of Ukraine and includes laws of Ukraine in the field of health, labor and environmental protection. In particular, based on the work of international and Ukrainian scientists in the field of security in Ukraine, the concept of education in the field of safety of human's life and activity is implemented, within which it is taught a set of disciplines on labor protection.

However, the current state of affairs suggests that future specialists formation of cultural safety peculiarities in the field of labor protection, especially under pandemic conditions, is insufficient and inconsistent. As security has become a priority goal and need of man, team and society as a whole, it is clear that the assimilation of this culture can be achieved through formation of the new system of views, values, norms and traditions of safe behavior.

The purpose of the article is to substantiate the peculiarities of the culture of safety in a pandemic for future labor protection specialists during professional training. The research methods are theoretical: analysis (impulse, system, analytical and synthetic, inductive, deductive); synthesis (general scientific, interdisciplinary, interdisciplinary); classification, systematization, generalization; modeling.

The results. The relevance and need to develop a culture of safety of future health and safety professionals under pandemic conditions during their professional training are substantiated. 
The significance of labor protection at work and other institutions, in social life under pandemic conditions is analyzed. The approaches that contribute to the formation of a culture of safety of future health and safety professionals (environmental, geophysical, medical and biological, algorithmic, strategic, informational, contextual, synergetic, gender, block practice) are substantiated.

The considered appropriate formulas and techniques in the approaches provide an opportunity to make a dynamic management decision to effectively consolidate knowledge and skills on safety culture of future professionals under modern conditions during professional training.

Conclusions. The proposed material will be of interest to teachers of higher education institutions in the field of labor protection and life safety. The research does not cover all the aspects of the problem of forming a safety culture under modern conditions. The prospect of further research requires the forming of the model that provides new principles, forms and methods of safety culture formation of future professionals in the field of labor protection.

Key words: safety culture, labour protection, modern conditions, higher education.

\section{References}

1. Abil'tarova, Je.N. (2018). Principy formirovanija kul'tury bezopasnosti professional'noj u budushhih specialistov po ohrane truda [Principles of formation of a culture of professional safety in future specialists in the field of labor protection]. Pedagogicheskoe obrazovanie v Rossii-Pedagogical education in Russia, 10, 76-84 [in Russian].

2. Bespal'ko, V.P. (1989). Slagaemye pedagogicheskoj tehnologii [The constituent parts of pedagogical technology]. Moskva: Pedagogika [in Russian].

3. Vaintraub, M.A. (2019). Profesiina pidhotovka fakhivtsiv $\mathrm{z}$ okhorony pratsi $\mathrm{u}$ haluzi osvity: osoblyvosti ta pidkhody [Professional training of educational protection educators: 
peculiarities and approaches]. Aktualni pytannia humanitarnykh nauk: mizhvuzivskyi zbirnyk naukovykh prats molodykh vchenykh Drohobytskoho derzhavnoho pedahohichnoho universytetu imeni Ivana Franka (25), 193-198 [in Ukrainian].

4. Honcharenko, S.U. (2008). Pedahohichni doslidzhennia: metodolohichni porady molodym naukovtsiam [Pedagogical research: methodological advice for young scientists]. Kyiv: Vinnytsia: DOV «Vinnytsia» [in Ukrainian].

5. Klymenko, K.P. (2017). Potentsial Orhanizatsii okhorony zdorovia Lihy Natsii $\mathrm{u}$ sferi borotby $\mathrm{z}$ infektsiinymy zakhvoriuvanniamy [Potential of the Organization of Health of the League of Nations in the field of control of infectious diseases]. Almanakh mizhnarodnoho prava - Almanac of International Law, (15), 73-85 [in Ukrainian].

6. Nakhod, S.A. (2014). Metodolhichni pidkhody do rozrobky tekhnolohii formuvannia prohnostychnykh umin [Methodological approaches to the development of technology for the formation of prognostic skills]. Visnyk dnipropetrovskoho universytetu imeni alfreda nobelia. seriia "pedahohika $i$ psykholohiia». Pedahohichni nauky - Bulletin of the Alfred Nobel University of Dnipropetrovsk. Series "Pedagogy and Psychology». Pedagogical sciences, 2(8), 74 [in Ukrainian].

7. Pidlasyi, I.P. (2004). Praktychna pedahohika abo try tekhnolohii. Interaktyvnyi pidruchnyk dlia pedahohiv rynkovoi systemy osvity [Practical pedagogy or three technologies. An interactive textbook for teachers of the market education system]. Kyiv: Slovo Publishing House [in Ukrainian].

8. Pometun, O.I. (2010). Osvita dlia stiikoho rozvytku innovatsii XXI stolittia [Education for sustainable development of innovations of the XXI century]. Shliakh osvity - The path of education, (3), 12-17 [in Ukrainian].

9. Postanova №16 (2020). Pro zatverdzhennia Tymchasovykh rekomendatsii shchodo orhanizatsii protyepidemichnykh zakhodiv pry zdiisnenni dozvolenykh vydiv diialnosti, yaki peredbachaiut pryimannia vidviduvachiv $\mathrm{V}$ ofisnykh prymishchenniakh na period karantynu u zviazku z poshyrenniam 
koranovirusnoi khvoroby (COVID - 19) [Resolution №16 (2020) On approval of the Interim Recommendations on the position on the organization of anti-epidemic measures in the issuance of permitted types of activities, providing for the accession of visitors in office premises at the quarantine period due to the spread of coronavirus desease (COVID - 19)]. [in Ukrainian].

10. Stepanova, O.O. Domina, O.O. Shulha, A.H. (2012). Rol liudskoho faktora $\mathrm{v}$ pytanniakh zabezpechennia promyslovoi bezpeky. [The role of the human factor in matters of industrial security]. Vestnyk KhNADU - Bulletin of KhNADU. (59), 135137. Retrieved from http://irbis-nbuv.gov.ua/.../ cgiirbis_64.exe?...DOWN...-mova ukr [in Ukrainian].

11. Report 2008-125. Forecasting skill needs: a review of national and European practices. Commissioned by the Norwegian Ministry of Education and Research (Kunnskapdepartementet). Retrieved from http://www.trainingvillage.gr/skillsnet.

12. Study visits programme for education and vocational training specialists 2010/11. Retrieved from http://www.trainingvillage.gr/skillsnet (under «Forecasting» section).

13. Vocational education and training - key to the future. Lisbon-Copenhagen-Maastricht: mobilising for 2010. Retrieved from http://www.trainingvillage.gr/skillsnet (under «Forecasting» section).

\section{Вступ}

Ситуація у сфері безпеки, що складається під впливом багатьох складнодинамічних процесів, посилилась антропогенним навантаженням навколишнього середовища завдяки пандемії, що супроводжується виникненням нових ризиків та загроз для людей. Тому питання безпеки життя та здоров'я людей розглядається як пріоритетне у контексті забезпечення сталого розвитку держави та суспільства в цілому. 
В Україні створена законодавча база, яка грунтується на Конституції України і включає закони України у сфері охорони здоров'я, охорони праці, охорони навколишнього середовища. Зокрема, на основі напрацювань міжнародних i українських науковців у сфері безпеки в Україні реалізується концепція освіти 3 напряму безпеки життя і діяльності людини, в рамках якої, зокрема, викладається комплекс дисциплін з охорони праці.

Разом $з$ тим, існуючий стан справ свідчить про те, що формування у майбутніх фахівців в галузі охорони праці особливостей безпеки культури, особливо в умовах пандемії, $€$ недостатнім і непослідовним. Оскільки безпека стала пріоритетною метою та потребою людини, колективу та суспільства в цілому, зрозуміло, що досягти засвоєння цієї культури можна лише за рахунок формування нової системи поглядів, цінностей, норм і традицій безпечної поведінки. Ця культура має базуватись на наукових та системних підходах. На думку зарубіжних дослідників Дж. Капрарі та Д. Сервона, люди здатні передбачати майбутнє та регулювати дії відповідно до особистих цілей, удосконалювати свій досвід, свої дії та особистісне зростання. (Капрара, \& Сервон, 2003; Study visits programme..., 2010; Vocational education..., 2010).

Недостатня увага приділяється особливостям культури безпеки, зокрема у закладах вищої освіти при підготовці фахівців в галузі охорони праці.

Метою статmі є обгрунтування особливостей культури безпеки в умовах пандемії у майбутніх фахівців 3 охорони праці під час професійної підготовки.

\section{Матеріал і методи дослідження}

У процесі дослідження було використано загальнонаукові й педагогічні методи дослідження: теоретичні: аналіз (порівняльний, системний, аналітикосинтетичний, індуктивний, дедуктивний) - для визначення поняття (культура безпеки в умовах пандемії у майбутніх фахівців з охорони праці під час професійної підготовки) та 
підходів; синтез (загальнонауковий, міжгалузевий, міжпредметний) - для обгрунтування єдності взаємопов'язаних підходів, формулювання висновку; класифікація, систематизація, узагальнення - 3 метою формування змістових узагальнень теоретичного матеріалу, визначення концептуальних положень, формул та прийомів; моделювання - для розроблення схеми єдності підходів щодо формування культури безпеки професійної діяльності у майбутніх фахівців з охорони праці в умовах пандемї.

\section{Результати та їх обговорення}

Право на здоров’я та безпечні умови праці - невід’ємне право кожної людини у будь-якій країні світу.

Загальновідомо, що економіка безпосередньо залежить саме від ефективності, якості продуктивності виробничого процесу. Таким чином, рівень розвитку економіки залежить наскільки повно і цивілізовано врегульовані відносини між учасниками трудових відносин, як підготовлені в університетській вищій освіті, зокрема, фахівці в галузі «охорона праці».

При цьому на безпеку, як базисну потребу людини, акцент зроблений і в Концепції Організації Об'єднаних Націй $(\mathrm{OOH})$ про «сталий людський розвиток». Відповідно до даної Концепції основною умовою сталого розвитку людства є вирішення проблеми безпеки людини. Першою цівілізованою установою ООН у 1946 році стала міжнародна організація праці (МОП), головною метою якої є поліпшення умов праці та життя працівників усіх країн.

Слід зауважити, що переважною більшістю членів МОП, куди входить Україна з 1954 року, та Всесвітньої організації охорони здоров'я, останнім часом прийнято рекомендації щодо праці в умовах пандемії COVID-19, зокрема, це стосується засобів індивідуального захисту, дезінфекції в приміщеннях тощо. 
Ухвалені в Україні заходи на законодавчому рівні спрямовані на протидію поширенню коронавірусної інфекції в навчальних закладах та інших сферах людської діяльності. В умовах глобальної пандемії коронавірусу стала нагальною потреба поліпшення культури безпеки у майбутніх фахівців з охорони праці під час професійної підготовки.

Ми погоджуємося 3 визначенням поняття безпеки культури, як інтегральна якість особистості, яка характеризується сукупністю професійних знань, умінь i навичок безпечного здійснення професійної діяльності та високим ступенем відповідальності, самоорганізації й саморозвитку, заснованих на глибокому усвідомленні пріоритету безпеки при вирішенні професійних завдань (Альбітарова, 2018).

На думку автора, достатньо повно особливостям формування культури безпеки професійної діяльності у майбутніх фахівців 3 охорони праці в сучасних умовах відповідають підходи, що відображені на рис.1.

Автор переконаний, що успіх з формування культури безпеки професійної діяльності у майбутніх фахівців 3 охорони праці в сучасних умовах залежить від єдності цих підходів.

Як видно з рис.1, один з основних підходів - медикобіологічний.

\section{Медико-біологічний підхід}

Створення Організації охорони здоров’я Ліги Націй ознаменувало початок нової ери міжнародного співробітництва у сфері боротьби 3 інфекційними хворобами. В компетенцію організації входило створення Комісії різних хвороб, гігієни, фізичної культури, стандартизації біологічних препаратів та інші міжнародні питання охорони здоров’я залишалися на порядку денному Ліги до 1939 р. Новою формою міжнародної діяльності 3 боротьби із епідеміями в кінці XX - на початку XXI ст. стало прийняття міжнародно-правових угод, спрямованих на 
розробку єдиних стандартів із захисту населення від передачі вірусів. Вони визначали права осіб, хворих небезпечними для людства інфекційними захворюваннями, а також обов'язки представників міжнародного співтовариства із запобігання їх поширення, ведення просвітницької роботи у сфері охорони здоров’я та стабілізації санітарно-епідеміологічної ситуації у світі (Клименко, 2017). Особливо гостро небезпека для людей проявляється під час пандемії (коли обов'язкова має бути зберігатись дистанція між людьми, відповідна ізольованість, присутність на обличчях масок тощо). В Міністерстві охорони здоров'я України с цього приводу вийшла постанова [9].

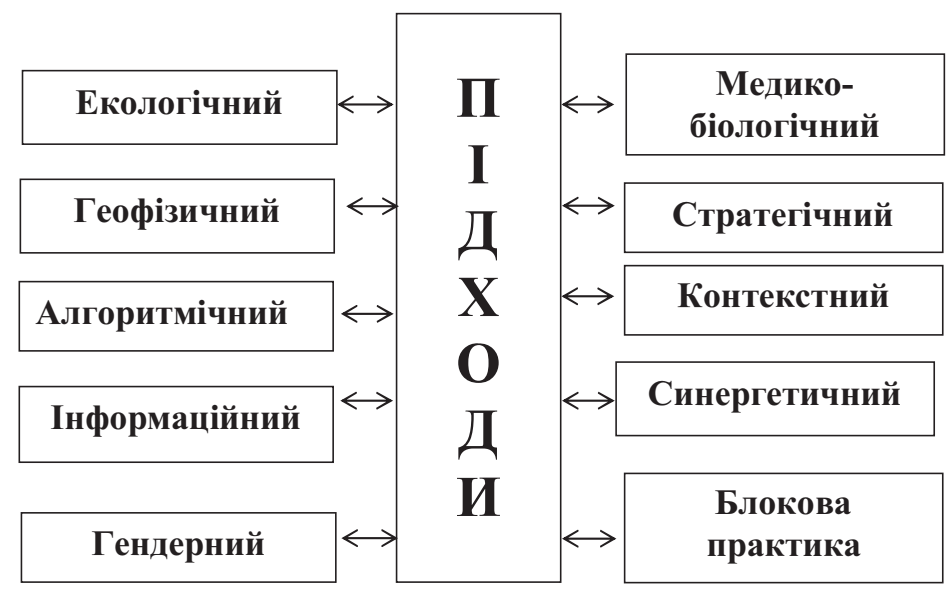

Рис.1 Сучасні підходи до формування культури безпеки професійної діяльності у майбутніх фахівців з охорони праці

Зідно цієї постанови, всім працівникам різних галузей діяльності рекомендовано: проводити температурний скринінг усім працівникам. На виробництві, в ЗВО та ін. місцях скоплення людей при проведенні вимірювання температури тіла контактним методом має бути забезпечуватись обов'язкова дезінфекція об'єкта, яким здійснюється термометрія. Самі працівники мають бути в 
респіраторах або захисних масках на дистанціюванні в 1,5 метра один від одного ( в розрахунку не більше однієї особи на 10 квадратних метрів площі).

Обмеження стосується і суб'єкта господарської діяльності. Має бути наявність рідкого мила, антисептиків та паперових рушників в санвузлах, вологе прибирання 3 використанням миючих та дизенфекційних засобів 3 провітрюванням кожні дві години. За вищеописаною постановою працівники мають: мити руки з рідким милом або обробляти їх спиртовмісними антисептиками не рідше, ніж раз на три години, утримуватись від контактів з особами, що мають симптоми респіраторних захворювань, самоізолюватись у разі виникнення цих симптомів.

На думку науковців, одним із провідних освітніх завдань в професійній підготовці будь-яких фахівців слід обов'язково внести формування компетентностей щодо прийняття безпечних професійних рішень і дій; розуміння взаємозв'язку i взаємозалежності людини й природи, усвідомлення необхідності збереження глобальної рівноваги та причетності кожного до проблем навколишнього середовища (Пометун, 2010).

Міжнародна організація праці (2015) наголошує на важливості й необхідності формування культури безпеки у працівників організацій. Враховуючи викладене вище, формулювання культури безпеки професійної діяльності в майбутніх спеціалістів 3 охорони праці $\epsilon$ актуальнім завданням сьогодення.

Водночас, розгляд цієї наукової проблеми вимагає пошуку та розробки нових методологічних підходів, що складають науково-методологічну базу дослідження.

На нашу думку, достатньо повно Ельвіза Альбітарова розглядається культуру безпеки як інтегральну якість особистості, що характеризується сукупністю професійних знань, умінь і навичок безпечного здійснення професійної 
діяльності та високим ступенем відповідальності, самоорганізації й саморозвитку, заснованих на глибокому усвідомленні пріоритету безпеки при вирішенні професійних завдань (Альбітарова, 2018).

Організація формування культури безпеки професійної діяльності у майбутніх фахівців з охорони праці під час професійної підготовки пов'язана з особливостями регіону, стану ЗВО в умовах пандемії. В багатьох $3 \mathrm{BO}$ впроваджується дистанційне навчання, різні технології дистанційного навчання, змішане навчання (поєднання очної форми й технологій дистанційного навчання), різні форми (денна, вечірня, заочна, екстернат на тощо) і методи проведення занять. Згідно наказів МОН, на території регіону,на якій установлено «померанчевий рівень» епідемічної небезпеки, заборонено відвідувати ЗВО групами кількістю більш, ніж 20 студентів.Така ситуація цілком виправдена, оскільки зберігає людей від ризику захворіти на COVID - 19.

Слід зауважити: формування культури безпеки професійної діяльності у майбутніх фахівців з охорони праці в сучасних умовах тісно пов'язано і з іншими підходами, що враховують здоров'я і безпеку життєдіяльності людей.

Розглянемо такі підходи.

Екологічний підхід враховує вплив багатьох екологічних факторів. Серед них: магнітні бурі, метозалежність, сонячні сплески та ін. кліматичні фактори, що здатні здійснювати прямий чи непрямий вплив на людину.

Високі і низькі температури, акустичні коливання, підвищення сонечної радіації та багато інших екологічних факторів можуть серйозно вплинути на здоров'я і життя людини, зокрема, і на реакцію іiі під час професійної діяльності. У зв'язку з цим, загальновідомо, наприклад, що магнітні бурі впливають на метеозалежних і літніх людей, гіпертоніків, гіпотоніків, людей, які схильні до 
психологічних i нервових розладів. Щоб мінізувати негативні наслідки для організму в такі дні, необхідно знати i використовувати особливий режим: знизити фізичні навантаження, уникати стресів, починати день контрастним душем, поменше сидіти за кермом, приймати лікувальні трави та ліки, раніше лягати спати, причому спати не менше 8 годин тощо. Ось чому використання екологічного підходу під час професійної підготовки майбутніх фахівців з охорони праці дозволить у них сформувати культуру безпеки в галузі екології, професійні знання і уміння щодо перетворення навколишнього середовища для безпечного здоров'я і життя людини, безпечних умов їі професійної діяльності.

Алгоритимічний та інформаційний підходи засновані: на особливості алгоритму у тому, що він являє собою інформацію і слугує джерелом для їі оброблення. У такому програмованому навчанні дії навчальної системи і дії студента пов'язані в одну цілісну систему під управлінням одного алгоритму; використанні всіх видів інформації, інформаційного аспекту будь-яких явищ.

Значний крок у розвитку алгоритмічного підходу до навчання зробив В. П. Беспалько (Беспалько, 1989), що подав дидактичний процес як сукупність двох алгоритмів: функціонування (система послідовних дій, що виконуються студентом) i управління (збір і оброблення необхідної інформації та прийняття рішень). Вчений прийшов до правильного висновку, що управлінський вплив педагога повинен бути диференційованим залежно від рівня засвоєння матеріалу.

Інформаційний підхід - один із сучасних загальнонаукових підходів, що тісно пов'язаний з усіма іншими підходами - системним, структурним, функціональним, імовірнісним, модельним тощо.

Синергетичний підхід

Синергетика нині стала якісно новим методологічним підходом у науковому пізнанні і механізмом оптимального 
управління педагогічними системами. Теорія самоорганізації (синергетика), що виникла в галузі досліджень нерівноважних природних систем, дає можливість поновому поглянути на складні педагогічні системи. Синергетика не спростовує основні принципи i закономірності освіти в цілому, не відміняє принципів системного, діяльнісного, особистісного та інших методологічних підходів, а доповнює та логічно продовжує (Наход, 2014). Основні закони педагогіки синергетикою розглядаються з позиції теорії складноорганізованих систем як еволюція розвитку освітніх процесів. Разом 3 междисциплінарністью синергетичного підходу важливою $є$ його трансдисциплінарність. Вона розкривається в таких рисах синергетичного підходу, як операція «через», «крізь» дисциплінарні межі при вивченні суб'єкта, як вихід «за межі» конкретних дисциплін (Гончаренко, 2008).

Як справедливо зазначає С. Гончаренко, «у педагогічному процесі явно проявляються взаємодії, які вивчаються синергетикою з їі ключовим положенням про відкритий характер будь-якої з соціальних систем - сучасною теорією спільної дії. У залежності від ступеня своєї відкритості системи взаємодіють між собою, причому у формі не лише боротьби протилежностей, яка раніше вважалася єдиним способом розвитку, а й співробітництва» (Гончаренко, 2008).

Стратегічний підхід

Стратегічний підхід вимагає розгляду процесу формування інформаційної системи в довгостроковому періоді часу. Ідеологія цього підходу заснована на відсутності можливості точного передбачення шляхів розвитку інформаційної системи підприємства на тривалому відрізку часу. Стратегічний підхід може розглядатися як технологія управління процесом формування та розвитку інформаційної системи в умовах нестабільності й невизначеності факторів зовнішнього і внутрішнього 
середовища. У цьому випадку основне завдання управління процесом формування та розвитку інформаційної системи полягає в розробці і реалізації сукупності напрямів діяльності в умовах, що змінюються.

Контекстний підхід

Усе більшого визнання в системі професійної освіти набуває контекстний підхід, заснований на кращих традиціях педагогіки і психології. Контекстний підхід передбачає моделювання та організацію навчального процесу за допомогою комплексу дидактичних форм, методів і засобів предметного та соціального змісту майбутньої професійної діяльності студентів. Навчальна діяльність стає особистісно значущою, оскільки в ній простежуються особливості майбутньої професії, завдяки чому створюються реальні можливості для розвитку не тільки навчально-пізнавальної, але й професійної мотивації студентів. Моделювання у змісті й способах організації навчання забезпечує перехід від теоретичного осмислення професійних знань до їх прикладного застосування. За такого підходу студенти не тільки дізнаються про можливі способи використання фахових знань у майбутній діяльності, але й отримують можливість відразу ж під час занять оперувати ними (Наход, 2014).

Отже, контекстний підхід сприяє підвищенню пізнавальної активності майбутніх фахівців; формуванню пізнавальної та професійної мотивації; формуванню ціннісного ставлення до професії; забезпеченню поступового переходу студентів від навчальної до професійної діяльності; сприяє максимальному наближенню змісту навчальної діяльності студентів до їхньої майбутньої професії.

Геофізичним підходом досліджується біоритми циклічні коливання інтелектуальної, фізичної й емоційної активності, зниження або підвищення атмосферного тиску. Формування культури безпеки у майбутніх фахівців 3 охорони праці за допомогою геофізичного підходу 
передбачає розгляд місцевих, регіональних особливостей, що також впливають на життя, здоров' я, реакцію, стан людей в повсякденному житті і під час професійної діяльності.

На розвиток життя, а, отже, на межі біосфери впливає багато факторів, наприклад, наявність кисню, вуглекислого газу, води в їі рідкій фазі. Обмежують область поширення життя занадто високі чи низькі температури, дефіцит або надлишок елементів мінерального харчування.

\section{Гендерний підхід}

На думку дослідників, гендерна ознака впливає на результат роботи у надзвичайних ситуаціях (Степанова, 2012). Так, за інших однакових умов жінки, як правило, травмуються із-за необережності набагато рідше, ніж чоловіки за рахунок більшої жіночої старанності та сумлінності при виконанні правил.

Встановлено також, що жінки працюють більш надійно та безпечно, ніж чоловіки, якщо діють у нормальних умовах (Вайнтрауб, 2019). Якщо умови роботи ускладнюються (виникають непередбачені обставини, втома чи встановлюється екстремальний режим праці), кількість порушень і помилок у їхній роботі буває більше, ніж у чоловіків; безпека, надійність роботи жінок істотно знижується порівняно з чоловіками. Більша кількість жінок гальмують у роботі через недооцінку своїх сил і здатностей, невпевненість, зайвої обережності.

У чоловіків нещасні випадки трапляються навпаки, через переоцінку своїх можливостей, слабкість до алкоголю тощо.

У зв'язку 3 цим, варто підмітити, що завдяки особливостям гендерної ознаки, під час професійної підготовки слід додатково розвинути у жінок і у чоловіків стійкість до впливу зовнішніх шкідливих факторів.

Значну роль у коригуванні людського фактора відіграє тренажерна підготовка 3 використанням ситуації екстремальних умов: дефіциту часу, нестачею інформації 
(невизначеності), додаткового введення більш складних завдань 3 використанням персонального комп'ютера, врахування гендерної ознаки тощо. Після отримання досвіду фахівці оволодівають фізичною та психологічною стійкістю, готовністю до дій у різних виробничих і життєвих ситуаціях.

Під час розгляду професійної компетентності фахівців з охорони праці важливого значення, як показали останні дослідження, набувають сформовані якості: комунікативність, креативність, самостійність, енергійність, ініціативність; знання нормативних законів тощо.

Отже, зміст викладання навчального матеріалу на всіх етапах навчально-виховного процесу має бути підпорядкований основній меті - формування необхідних компетентностей у фахівців з охорони праці в інженерній та педагогічній галузях.

Блокова практика

Один $з$ поширених i перспективних підходів для поліпшення пам'яті та ефективного навчання запровадив Dick Schmidt з Каліфорнійського університету і назвав його блоковою практикою. Суть цього підходу в тому, що вивчення матеріалу проходить через багаторазове повторення i чергування інформації блоками протягом тривалого часу. Автор переконаний, що зазначений підхід «блокова практика» допомагає з'ясувати і нову інформацію, оскільки підхід заснований на природній здатності мозку до розпізнавання образів і відмінностей між ними.

Впроваджені підходи мають бути добре усвідомленими студентами. Теоретичні знання і уміння, апробовані на практиці на достатній кількості тренувальних вправ дасть можливість закріпити уміння, зробити їх довготривалими.

Кількість тренувальніх вправ, інформаційна засвоюваність навчального матеріалу можна розрахувати за формулою:

$$
\text { Iз = Iт ( } \mathbf{1}-\mathbf{K} / Д) \text { H ( } \mathbf{1}) \text {, де Iз - інформаційна }
$$
засвоюваність навчального матеріалу, Iт - повна інформація 
навчального матеріалу, $\mathbf{K}$ - числовий коефіцієнт, що показує пропускну здатність короткочасної пам'яті $(\mathbf{0 , 0 6}<\mathbf{K}<\mathbf{0 , 0 8})$, Д - числовий коефіцієнт, що показує пропускну здатність довгострокової пам'яті $(\mathbf{4}<Д<8)$, Н - кількість повторень (Підласий, 2004).

Велике значення під час професійної підготовки має бути попередження можливих помилок при закріпленні матеріалу. У цьому аспекті вирішальним $є$ старанність початкового засвоєння і першого закріплення матеріалу, правильність його розуміння. (Підласий, 2004).

\section{Висновки}

Обгрунтовано актуальність і необхідність розвивати культуру безпеки в умовах пандемії у майбутніх фахівців 3 охорони праці під час професійної підготовки.

Проаналізовано значущість охорони праці на виробництві та інших закладах, у соціальному житті в умовах пандемії. Обгрунтовано підходи, що сприяють формуванню культури безпеки професійної діяльності у майбутніх фахівців 3 охорони праці (екологічний, геофізичний, медико-біологічний, алгоритмічний, стратегічний, інформаційний, контекстний, синергетичний, гендерний, блокова практика).

Розглянуті відповідні формули та прийоми у підходах надають можливість прийняття динамічного управлінського рішення для ефективного закріплення знань i умінь 3 культури безпеки в умовах пандемії у майбутніх фахівців під час професійної підготовки.

Запропонований матеріал буде цікавий викладачам закладів вищої освіти у галузі охорони праці та безпеки життєдіяльності. Дослідження не вичерпує всіх аспектів проблеми формування культури безпеки в умовах пандемії. Перспектива подальшого дослідження потребує розробки моделі, яка передбачає нові принципи, форми і методи формування культури безпеки у майбутніх фахівців у галузі охорони праці. 


\section{Література}

1. Абильтарова Э.Н. Принципы формирования культуры безопасности профессиональной у будущих специалистов по охране труда. Педагогическое образование в России, 2018 (10), С. 76-84.

2. Беспалько В.П. Слагаемые педагогической технологии. Москва: Педагогика, 1989.

3. Вайнтрауб М.А. Професійна підготовка фахівців 3 охорони праці у галузі освіти: особливості та підходи. Актуальні питання гуманітарних наук: міжвузівський збірник наукових праць молодих вчених Дрогобиџького держсавного педагогічного університету імені Івана Франка I [редактори-упорядники В. Ільницький, А. Душний, I. Зимомря], 2019. Вип. 25. С. 193-198.

4. Гончаренко С.У. Педагогічні дослідження: методологічні поради молодим науковцям. Київ Вінниця: ДОВ «Вінниця», 2008. 278 с.

5. Клименко К.П. Потенціал Організації охорони здоров’я Ліги Націй у сфері боротьби 3 інфекційними захворюваннями. Альманах міжнародного права, 2017 (15), С. $73-85$.

6. Наход С.А. Методолгічні підходи до розробки технології формування прогностичних умінь. Вісник дніпропетровського університету імені Альфреда Нобеля. серія «Педагогіка і психологія». Педагогічні науки, 2014. № 2 (8) С. 74.

7. Підласий І.П. Практична педагогіка або три технологіі. Інтерактивний підручник для педагогів ринкової системи освіти. Київ:Видавничий Дім «Слово», 2004. 616 с.

8. Пометун О.I. Освіта для стійкого розвитку інновацій XXI століття. Шлях освіти,2010. (3), С. 12-17.

9. Постанова №16 від 9.0.5.2020. Про затвердження Тимчасових рекомендацій щодо організації протиепідемічних заходів при здійсненні дозволених видів діяльності, які передбачають приймання відвідувачів в офісних приміщеннях на період карантину у зв'язку 3 
поширенням корановірусної хвороби (COVID - 19).

10. Степанова О.О., Дьоміна О.О., Шульга А.Г. Роль людського фактора в питаннях забезпечення промислової безпеки. Вестник ХНАДУ, 2012, Вип. 59. С. 135-137. URL : irbis-nbuv.gov.ua/.../cgiirbis_64.exe?...DOWN... - мова укр.

11. Report 2008-125. Forecasting skill needs: a review of national and European practices. Commissioned by the Norwegian Ministry of Education and Research (Kunnskapdepartementet). URL: http://www.trainingvillage.gr/ skillsnet.

12. Study visits programme for education and vocational training specialists 2010/11. URL: http://www.trainingvillage.gr/ skillsnet (under «Forecasting» section).

13. Vocational education and training - key to the future. Lisbon-Copenhagen-Maastricht: mobilising for 2010. URL: http://www.trainingvillage.gr/skillsnet (under «Forecasting» section)

\section{Вайнтрауб М.А.}

Сучасні підходи до формування культури безпеки професійної діяльності у майбутніх фахівців 3 охорони праці

\section{Аннотація}

Стаття присвячена проблемі щодо особливостей формування культури безпеки професійної діяльності у майбутніх фахівців з охорони праці в умовах пандемії.

Обгрунтовано актуальність і необхідність розвивати культуру безпеки в сучасних умовах у майбутніх фахівців 3 охорони праці під час професійної підготовки.

Проаналізовано значущість охорони праці на виробництві та інших закладах, у соціальному житті в 
умовах пандемії. Обгрунтовано підходи, що сприяють формуванню культури безпеки професійної діяльності у майбутніх фахівців 3 охорони праці (екологічний, геофізичний, медико-біологічний, алгоритмічний, стратегічний, інформаційний, контекстний, синергетичний, гендерний, блокова практика).

Розглянуті відповідні формули та прийоми у підходах надають можливість прийняття динамічного управлінського рішення для ефективного закріплення знань і умінь 3 культури безпеки в умовах пандемії у майбутніх фахівців під час професійної підготовки.

Запропонований матеріал буде цікавий викладачам закладів вищої освіти у галузі охорони праці та безпеки життєдіяльності.

Ключові слова: культура безпеки, охорона праці, сучасні умови ї, вища освіта.

\section{Вайнтрауб М.А.}

Современные подходы к формирования культуры безопасности профессиональной деятельности у будущих специалистов по охране труда

\section{Аннотация}

Статья посвящена проблеме особенностей формирования культуры безопасности профессиональной деятельности у будущих специалистов по охране труда в современных условиях.

Обоснована актуальность и необходимость развивать культуру безопасности в условиях пандемии у будущих специалистов по охране труда при профессиональной подготовке.

Проанализированы значимость охраны труда на производстве и других учреждениях, в социальной жизни в 
условиях пандемии. Обоснованы подходы, способствующие формированию культуры безопасности профессиональной деятельности у будущих специалистов по охране труда (экологический, геофизический, медико-биологический, алгоритмический, стратегический, информационный, контекстный, синергетический, гендерный, блочная практика).

Рассмотрены соответствующие формулы и приемы в подходах предоставляют возможность принятия динамического управленческого решения для эффективного закрепления знаний и умений по культуре безопасности в условиях пандемии у будущих специалистов во время профессиональной подготовки.

Предложенный материал будет интересен преподавателям высших учебных заведений в области охраны труда и безопасности жизнедеятельности.

Ключевые слова: культура безопасности, охрана труда, современные условия, высшее образование. 